Gut, 1985, 26, 1327-1332

\title{
Cigarette smoking, gastric acid secretion, and serum pepsinogen I concentrations in duodenal ulcer patients
}

\author{
F PARENTE, M LAZZARONI, ORNELLA SANGALETTI, STEFANIA BARONI, \\ AND G BIANCHI PORRO
}

From the Gastrointestinal Unit, 'L.Sacco' Hospital, Milan, Italy

SUMmaRY Cigarette smoking has been linked with duodenal ulcer disease although the mechanism of this association is unclear. This study assessed basal gastric secretory response to acute smoking of smokers with an active duodenal ulcer; in addition the possible effects of chronic smoking on gastric secretory capacity, as expressed by pentagastrin stimulated gastric acid secretion and fasting serum pepsinogen I (PG I) concentrations, were investigated in patients with active duodenal ulcer, or non-ulcer dyspepsia. In 10 smokers with duodenal ulcer smoking four cigarettes during 40 minutes did not influence basal gastric secretion of acid and pepsin, or serum PG I and gastrin concentrations. In 136 patients with duodenal ulcer and 90 controls with non-ulcer dyspepsia, pentagastrin stimulated acid secretion and fasting serum PG I concentrations were significantly higher among habitual heavy smokers than among nonsmokers. These findings suggest that in heavy smokers with duodenal ulcer acid- and pepsin-secreting cell function is not affected by acute cigarette smoking. By contrast, chronic cigarette smoking seems to be associated either with an increase of parietal- and chief-cell mass, or with an enhancement of their secretory capacity.

Cigarette smoking has been usually claimed to be a risk factor in the pathogenesis of duodenal ulcer disease, but the available evidence in favour of a causal relationship between smoking and duodenal ulcer is suggestive, and not conclusive. ${ }^{1}$ Three sets of data support such an association: firstly, epidemiological studies have shown higher prevalence of peptic ulcer in smokers than in non-smokers, ${ }^{2-4}$ secondly, it has been observed that individuals affected by duodenal ulcer smoke more and start smoking at an earlier age than do subjects without ulcer, ${ }^{5}$ and finally, several clinical trials have documented that smoking influences duodenal ulcer healing and relapse. Significantly higher ulcer healing rates and less frequent recurrences have been reported by many authors in non-smoking, than in smoking patients treated with different drugs. ${ }^{6-10}$

Studies of the acute effects of cigarette smoking on gastric acid and pepsin secretion have shown conflicting results. ${ }^{11-14}$ With the exception of a few preliminary reports, ${ }^{15-18}$ no information is available about the chronic effects of smoking on parietal- and chief-cell function.

Address for correspondence: G Bianchi Porro, Gastrointestinal Unit, 'L.Sacco' Hospital, Via G B Grassi, 74, 20157 Milano, Italy.

Received for publication 8 February 1985.
The purpose of the present study was two-fold: firstly to evaluate the effects of acute smoking on basal gastric secretion of acid and pepsin and on serum concentrations of gastrin and group I pepsinogens (PG I) in smokers with an active duodenal ulcer and secondly, to investigate the hypothesis that habitual heavy smokers with duodenal ulcer, or non-ulcer dyspepsia, have higher peak acid output (PAO) values and serum PG I concentrations than similar patients who have never smoked.

\section{Methods}

PART 1

\section{PATIENTS}

Ten male patients, with endoscopically diagnosed active duodenal ulcer, participated in this study. All patients were habitual cigarette smokers, with a mean consumption of 23 (range 15-40) cigarettes per day. Their age was $21-48$ years (mean 34 years); their mean $\pm S D$ peak acid output to $6 \mu \mathrm{g} / \mathrm{kg}$ pentagastrin subcutaneously (Peptavlon, ICI, Great Britain) was $54.9 \pm 14.6 \mathrm{mmol} / \mathrm{h}$. All subjects gave their informed verbal consent before admission to the study. 
PROCEDURE

All medication was discontinued 72 hours before the study. Each fasting patient, with smoking prohibited for at least 10 hours before each test, underwent in a random order two experiments with at least two days' interval. On the first experimental morning, the tip of a nasogastric double lumen tube (Salem 18 $\mathrm{Fr}$,) was positioned under fluoroscopic control in the gastric antrum. After aspirating and discarding the resting gastric secretion and the first 30 minutes of basal collection, ${ }^{19}$ basal secretion was continuously collected in 30 minute periods by using intermittent suction. Blood samples for PG I and gastrin determination were collected throughout the experiment at 20 minute intervals. Blood was centrifuged after clotting and serum immediately stored at $-20^{\circ} \mathrm{C}$ until assayed.

After initial 60 minute basal period, each subject smoked four filter cigarettes during 40 minutes, taking care to inhale. Each cigarette had an approximate nicotine content of $1.6 \mathrm{mg}$. As it has been shown that in smokers about $25 \%$ of the nicotine content of cigarette is absorbed, ${ }^{20}$ each patient received a dose of nearly $1.5 \mathrm{mg}$ of nicotine during 40 minutes.

The gastric secretory response and the pattern of serum PG I and gastrin were followed during the smoking period and for a further 80 minutes. An identical procedure was followed for the second experiment which was used as control, because the patient did not smoke throughout the study.

\section{ANALYTICAL PROCEDURES}

Gastric collections were analysed for volume, $\mathrm{pH}$, acid concentration and peptic activity. The acidity was determined by titration to $\mathrm{pH} 7 \mathrm{using} 0.1 \mathrm{mmol} / \mathrm{l}$ sodium hydroxide with an automatic titrator (Autoburette, Radiometer, Copenhagen). Peptic activity was measured according to the method of Berstad. ${ }^{21}$ Acid and pepsin output were calculated for 60 minute periods. Serum PG I concentrations were determined by a commercial radioimmunoassay kit (Pepsik, Sorin Biomedica, Saluggia, Italy) which provides a detection limit of $1 \mathrm{ng} / \mathrm{ml}$ with intra- and interassay variation of $7 \%$ and $10 \%$ respectively. Reference range in our laboratory for PG I is 20-80 $\mathrm{ng} / \mathrm{ml}{ }^{22}$ Concentration of gastrin was determined using a commercial RIA kit (Becton Dickinson, Orangeburg, New York) with normal range up to $100 \mathrm{pg} / \mathrm{ml}$.

PART 2

PATIENTS

One hundred and thirty six of 178 patients with endoscopically diagnosed active duodenal ulcer referred to our Unit from December 1982 to June 1984 were admitted to this part of the study. Eighty of these (56 men and 24 women), mean age 38.8 years (range 23-63 years), were habitual heavy cigarette smokers ( $>15$ cigarettes/day in the past two years), while 56 (40 men and 16 women), average age $41 \cdot 1$ (range 21-60 years) never smoked. Accurate information about smoking habits, duration of dyspeptic symptoms, previous complications, family history of peptic ulcer and daily consumption of alcohol was collected from each patient before entry to the study. Patients smoking $<15$ cigarettes/ day, those smoking for less than two years and those smoking pipes, or cigars, were excluded from the study.

Ninety patients in whom a diagnosis of non-ulcer dyspepsia had been made during the same period were used as controls. Under the term non-ulcer dyspepsia we included patients complaining of upper digestive tract discomfort - for example, epigastric pain, feeling of fullness, belching without any organic disease of oesophagus, stomach, duodenum, biliary system, or pancreas. Among these patients, 45 ( 24 men and 21 women), aged 18-60 years (mean 39.6), never smoked, while 45 ( 25 men and 20 women), average age 38.9 years (range 26-58 years), were habitual heavy smokers, according to the criteria previously defined. All medication was discontinued 72 hours before the study. In each subject after an overnight fast and without smoking for at least 10 hours before, basal and pentagastrin-stimulated $(6 \mu \mathrm{g} / \mathrm{kg}$ subcutaneously) acid outputs were determined.

Blood samples for PG I estimation were collected on the same morning before the gastric function test. Serum PG I concentrations were determined as above.

STATISTICAL ANALYSIS

Student's $t$ test for paired samples was used to determine the significance of the changes in acid and pepsin output and in serum PG I and gastrin concentrations during smoking and control experiment. Chi-square, Student's $t$ test for unpaired samples and Mann-Whitney $U$ test were used as appropriate for the statistical evaluation of the second part of the study. Differences with $p<0.05$ were considered significant.

\section{Results}

PART 1

The effects of cigarette smoking on basal gastric output of acid and pepsin are summarised in Figure 1. There was a small and not significant difference in acid and pepsin output of the first basal hour 

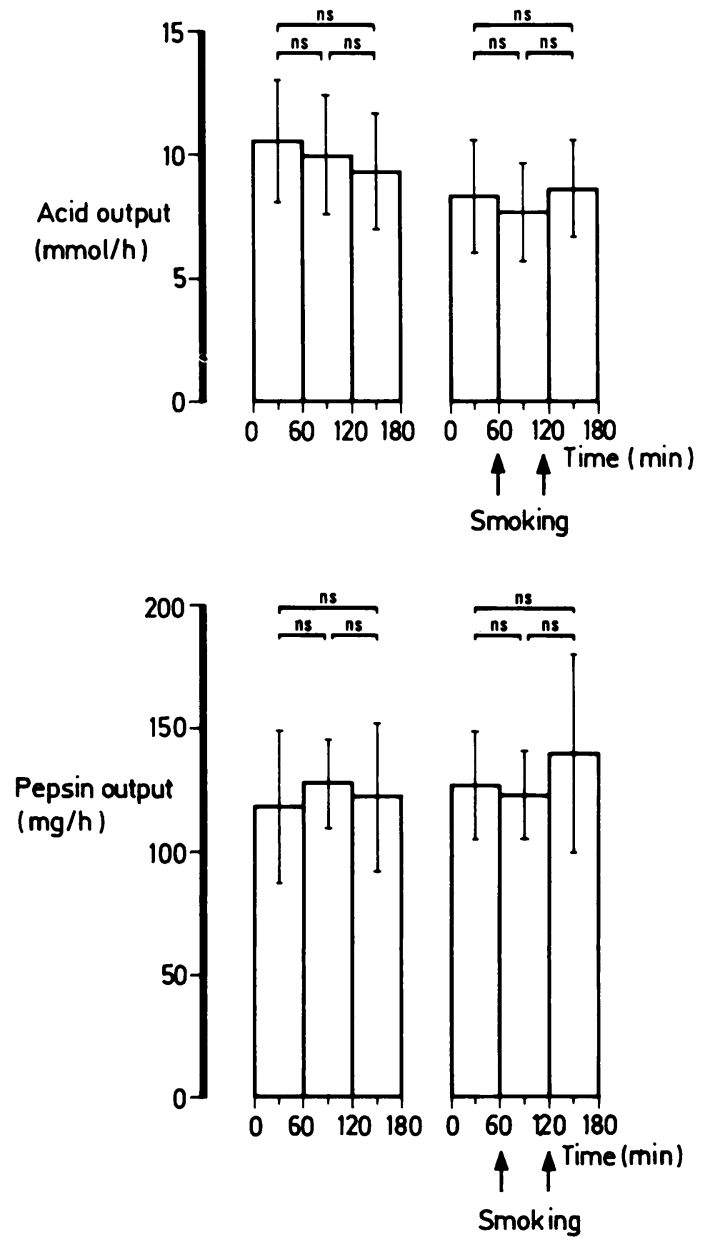

Fig. 1 Acid and pepsin output (mean $\pm S D$ ) during control and smoking experiment in 10 smokers with duodenal ulcer.

measured on the two experiments: acid output averaged $10 \cdot 4 \pm 5 \cdot 1(\mathrm{SD}) \mathrm{mmol} / \mathrm{h}$ during control test and $8 \cdot 2 \pm 4 \cdot 7(\mathrm{SD}) \mathrm{mmol} / \mathrm{h}$ during smoking test, while mean pepsin output was $120 \cdot 2 \pm 60 \cdot 6$ (SD) $\mathrm{mg} / \mathrm{h}$ and $129.9 \pm 49.6(\mathrm{SD}) \mathrm{mg} / \mathrm{h}$ respectively. Moreover during control and smoking days no significant changes in acid and pepsin output were observed during the second and the third hour, compared with the first hour. Serum gastrin and PG I concentrations in response to cigarette smoking are in Figure 2. No significant variations in the mean basal concentrations of serum gastrin and PG I were recorded on the two separate occasions. The mean concentrations of serum gastrin and PG I remained essentially unchanged during smoking and control test.
PART 2

Duodenal ulcer patients had significantly higher PG I concentrations (median $94 \mathrm{ng} / \mathrm{ml}$, range 45-181) than subjects with non-ulcer dyspepsia (median 70.5 $\mathrm{ng} / \mathrm{ml}$, range $28-128-\mathrm{z}=5 \cdot 96, \mathrm{p}<0 \cdot 01$ ). Significantly higher PAO values were also found in patients with duodenal ulcer (median $42 \mathrm{mmol} / \mathrm{h}$, range 18-92) in comparison with dyspeptic subjects (median $33 \mathrm{mmol} / \mathrm{h}$, range $11-55-\mathrm{z}=6 \cdot 50, \mathrm{p}<0 \cdot 01$ ). The two groups of smoking and non-smoking duodenal ulcer patients were comparable for age, sex, duration and age of onset of dyspeptic symptoms, past complications, family history of peptic ulcer and daily alcohol consumption (Table).

Serum PG I as well as PAO were significantly higher in habitual heavy cigarette smokers than in non-smokers of both study populations. In smoking duodenal ulcer group the median serum PG I was $103 \mathrm{ng} / \mathrm{ml}$ (range 45-159) in comparison with 77 $\mathrm{ng} / \mathrm{ml}$ (range 47-181) of non-smoking patients $(\mathrm{z}=5 \cdot 17, \mathrm{p}<0.01)$; the median PAO was $49 \mathrm{mmol} / \mathrm{h}$ (range 31-92) in duodenal ulcer smokers and 39 $\mathrm{mmol} / \mathrm{h}$ (range 18-71) in non-smokers $(\mathrm{z}=4.02$, $\mathrm{p}<0.01$ - Fig. 3). Similarly, smoking subjects with non-ulcer dyspepsia had a median serum PG I of 83 $\mathrm{ng} / \mathrm{ml}$ (range 46-128) in comparison with $61 \mathrm{ng} / \mathrm{ml}$ (range 28-96) of non-smokers $(\mathrm{z}=5 \cdot 12, \mathrm{p}<0.01)$; the median PAO was $36 \mathrm{mmol} / \mathrm{h}$ (range 20-55) and $29 \mathrm{mmol} / \mathrm{h}$ (range 11-50) in the two subgroups respectively $(z=3.68, p<0.01-$ Fig. 4$)$.

\section{Discussion}

The available data concerning the acute effects in humans of cigarette smoking on basal, or stimulated gastric acid and pepsin secretion are controversial. Smoking one, or a few cigarettes may stimulate $^{142324}$ inhibit $^{1125}$ or have no effect ${ }^{12}{ }^{13}$ on gastric acid and pepsin secretion. Such disparity

\section{Table Characteristics of duodenal ulcer patients}

\begin{tabular}{lll}
\hline & Smokers & Non-smokers \\
\hline $\begin{array}{l}\text { Cases (no) } \\
\text { Age: mean (years) } \pm \text { SE }\end{array}$ & $80\left(560^{\prime}, 24 \%\right)$ & $56\left(400^{\prime}, 16 \%\right)$ \\
$\begin{array}{c}\text { Duration of symptoms, } \\
\text { mean (months) } \pm \text { SE }\end{array}$ & $87 \cdot 8 \pm 1 \cdot 1$ & $41 \cdot 1 \pm 1 \cdot 4$ \\
$\begin{array}{c}\text { Age of onset of symptoms, } \\
\quad \text { mean (years) } \pm \text { SE }\end{array}$ & $32 \cdot 0 \pm 1 \cdot 1$ & $33 \cdot 7 \pm 1 \cdot 6$ \\
$\begin{array}{c}\text { Previous complications: } \\
\text { haemorrage }(\%)\end{array}$ & $3 \cdot 7$ & $5 \cdot 4$ \\
$\begin{array}{c}\text { Family history of } \\
\text { peptic ulcer }(\%)\end{array}$ & $32 \cdot 5$ & $37 \cdot 5$ \\
$\begin{array}{c}\text { Alcohol consumers }(\%) \\
\quad(>50 \text { g/day) }\end{array}$ & $26 \cdot 2$ & $21 \cdot 4$ \\
\hline
\end{tabular}




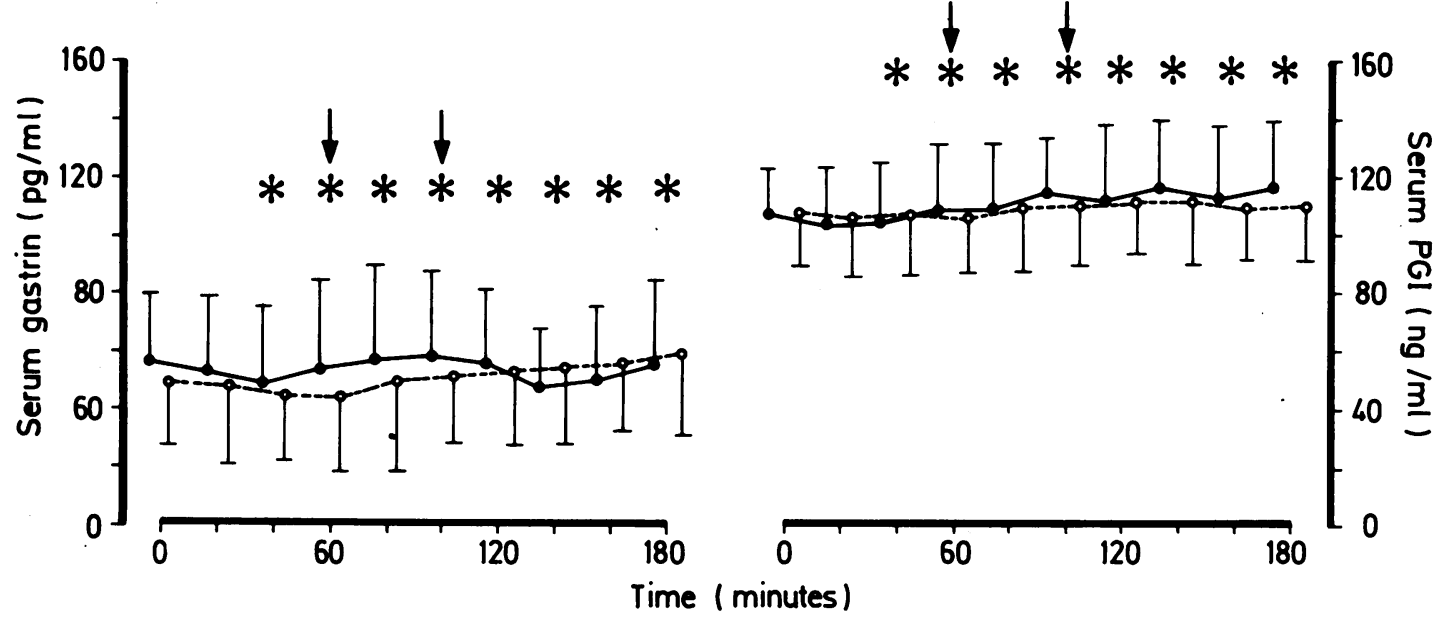

Fig. 2 Serum gastrin and pepsinogen I (PG I) (mean \pm SD) during smoking $(-\quad-O)$ and control $\left(\mathrm{O}_{----}-\mathrm{O}\right)$ experiment. $\downarrow-\downarrow$ smoking period. Each value both of smoking and control study was statistically compared with the initial basal value. ${ }^{*} p=n . s$.

between studies may be explained, in part, by the wide differences in the number and in the nicotine content of cigarettes smoked, particularly if there is a dose dependent response of the stomach to smoking. In this connection it has been shown that nicotine, which is probably the main factor responsible for the effects of smoking on the gastrointestinal tract, ${ }^{27}$ may stimulate or depress autonomic ganglia, depending on the dose. ${ }^{28}$ Many of the abovementioned studies, however, should be regarded with caution. In those studies examining the influence of smoking on submaximal pentagastrinstimulated gastric secretion, a weak stimulatory effect of acute smoking, if any, might be obscured by pentagastrin-induced stimulation. The studies of the effect of smoking on basal gastric secretion lack adequate controls. As there is marked intraindividual variability of basal gastric secretion during continuous collection for several hours, ${ }^{29}$ it is necessary to use the same individual as his own control and to repeat the study on separate two days, with and without smoking, in order to confirm that the observed variations in acid and pepsin output during smoking are not merely random fluctuations of the basal gastric secretory state.

The first part of the present controlled study has
Fig. 3 Serum pepsinogen I (PGI) and peak acid output in smokers and non-smokers affected by duodenal ulcer.

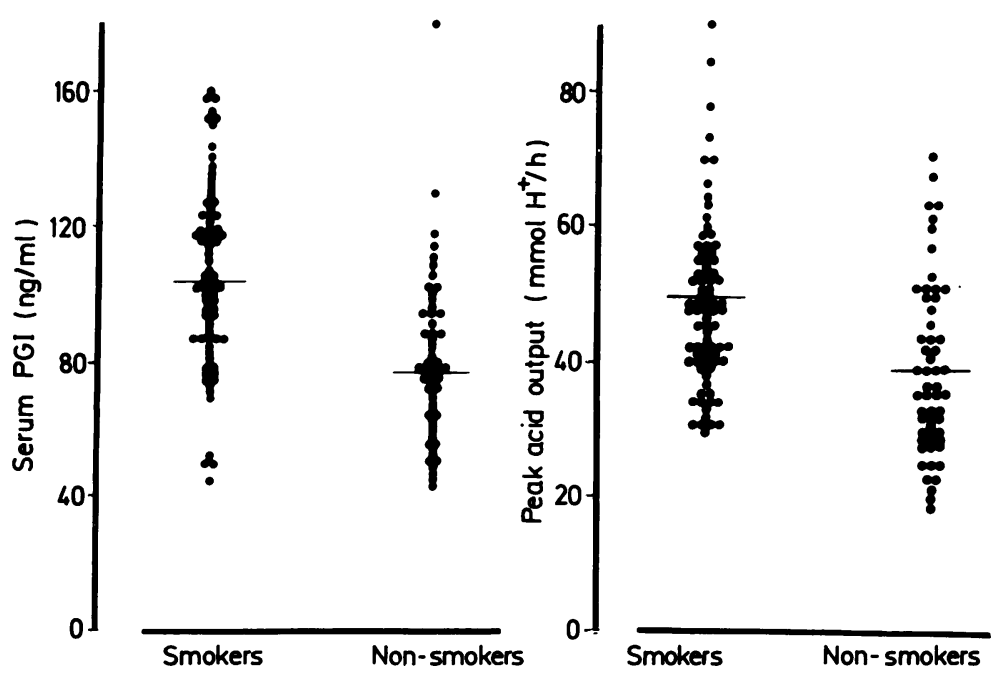


Fig. 4 Serum pepsinogen I (PGI) and peak acid output in smokers and non-smokers with non-ulcer dyspepsia.

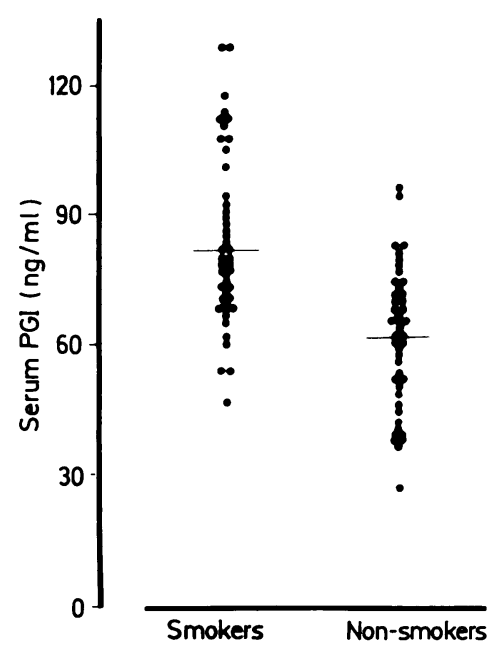

shown that in smokers with duodenal ulcer smoking four cigarettes during 40 minutes - which we believe may well reproduce the 'acute smoking episodes' of a heavy smoker - causes no significant changes in the basal gastric output of acid and pepsin. In addition, insignificant fluctuations of fasting serum gastrin and PG I concentrations have been reported in response to smoking. The second part has explored the possibility that habitual heavy cigarette smokers have increased values of PAO and fasting serum PG I in comparison with those who never smoked. We have shown that heavy smokers with duodenal ulcer, or non-ulcer dyspepsia, have significantly higher PAO values and fasting serum PG I than comparable non-smoking patients. These data are in agreement with those reported in healthy volunteers. $^{1718}$

The present study provides, therefore, two sets of data which apparently contradict each other. In smokers with duodenal ulcer smoking four cigarettes during 40 minutes does not exert a stimulatory effect on acid- and pepsin-secreting cells, while chronic smoking seems to be associated with increased stimulated gastric acid secretion and serum PG I. If PAO and PG I can be considered as indices of the parietal- and chief-cell masses respectively, ${ }^{30}{ }^{1}$ it seems that chronic cigarette smoking may lead either to increased parietal- and chief-cell mass, or to an enhancement of their secretory capacity. There are two possible explanations which could account for this discrepancy: (1) smoking may have a weak stimulatory effect on parietal and chief gastric cells so that habitual heavy smokers, already stimulated by chronic smoking, do not show an additional effect due to acute smoking. In support of this hypothesis, Fung and Tye reported a different pattern of gastric acid secretion in response to acute smoking between smokers and non-smokers. ${ }^{26}$ (2) alternatively, also in the absence of an acute demonstrable effect on oxyntic cells, smoking may chronically lead to an increased parietal- and chiefcell secretory capacity through indirect mechanisms, for example through a vagal pathway. A similar discrepancy has been described in rats for the effects of nicotine on gastric secretion. Acute administration of 'smoking doses' of nicotine decreases the volume of gastric juice and acid and pepsin output, ${ }^{32}$ while by chronic administration it increases volume, acid and pepsin output ${ }^{33}$ through a vagal pathway. ${ }^{3435}$

In man preliminary data ${ }^{15-18}$ suggest the hypothesis that cigarette smoking may elicit chronic vagal stimulation and in turn enhance gastric acid and pepsin secretory capacity. This effect of smoking would be similar to the significant increase of stimulated acid secretion values observed in humans after long term cholinergic therapy ${ }^{36}$ and in dogs after chronic sham-feeding ${ }_{37}^{37}$ which presumably acts through vagal stimulation. ${ }^{38}$ Additional support for this hypothesis is provided by our results, which suggest the possibility of either an enhancement of the parietal- and chief-cell mass, or an increase in their secretory capacity as result of chronic cigarette smoking.

The authors are indebted to Dr K G Wormsley for helpful suggestions and criticisms. Special thanks are due to Dr Nicoletta De Cesare for her assistance in preparing the manuscript and to Dr Patrizio Sala, Biostatistic Unit, Instituto De Angeli, Milano, for statistical advice. 


\section{References}

1 Wormsley KG. Smoking and duodenal ulcer. Gastroenterology 1978; 75: 135-52.

2 Jedrychowski W, Popiela T. Association between the occurrence of peptic ulcers and tobacco smoking. Public Health 1974; 88: 195-200.

3 Friedman GD, Siegelaub AB, Seltzer CC. Cigarettes, alcohol, coffee and peptic ulcer. $N$ Engl J Med 1974; 290: 469-73.

4 Gillies MA, Skyring A. Gastric and duodenal ulcer. The association between aspirin ingestion, smoking and family history of ulcer. Med J Aust 1969; 2: 280-5.

5 Monson RR. Cigarette smoking and body form in peptic ulcer. Gastroenterology 1970; 58: 337-44.

6 Lam SK, Lam KC, Lai CL, Yeung CK, Yam LYC, Wong WS. Treatment of duodenal ulcer with antacid and sulpiride. Gastroenterology 1979; 76: 315-22.

7 Bianchi Porro G, Prada A, Petrillo M, Lazzaroni M. Women and duodenal ulcer. Br Med J 1981; 283: 235.

8 Korman MG, Hansky J, Eaves ER, Schmidt GT. Influence of cigarette smoking on healing and relapse in duodenal ulcer disease. Gastroenterology 1983; 85: 871-4.

9 Ippoliti A, Elashoff J, Valenzuela J et al. Recurrent ulcer after successful treatment with cimetidine or antacid. Gastroenterology 1983; 85: 875-80.

10 Sontag S, Graham DY, Belsito A et al. Cimetidine, cigarette smoking and recurrence of duodenal ulcer. $N$ Engl J Med 1984; 311: 689-93.

11 Wilkinson AR, Johnston D. Inhibitory effect of cigarette smoking on gastric secretion stimulated by pentagastrin in man. Lancet 1971; 2: 628-32.

12 Debas HT, Cohen MM, Holubitsky IB, Harrison RC. Effect of cigarette smoking on human gastric secretory responses. Gut 1971; 12: 93-6.

13 Whitecross DP, Clarke AD, Piper DW. The effect of cigarette smoking on human gastric secretion. Scand $J$ Gastroenterol 1974; 9: 399-403.

14 Murthy SNS, Dinoso VP, Clearfield HR, Chey WY. Simultaneous measurement of basal pancreatic, gastric acid secretion, plasma gastrin and secretin during smoking. Gastroenterology 1977; 73: 758-61.

15 Withfield PF, Hobsley M. Smoking and gastric hypersecretion in duodenal ulcer patients. [Abstract]. Gut 1979; 20: A919.

16 Ligny G, Verelest R, Smets P. Etude de la consommation de cigarettes et de son influence sur les debits acides maximaux a la pentagastrine chez de temoins, des malades atteints d'ulcère duodenal et de gastrite atrophique. Gastroenterol Clin Biol 1980; 4: 348-55.

17 Sategna-Guidetti C, Di Napoli A, Pelissero A, Peyre S. Smoking and serum group I pepsinogen (PG I) levels. [Abstract 979] Scand J Gastroenterol 1982; 17: suppl 78: 247.

18 Massarat S, Enshai F, Veith R. Increased gastric acid and pepsin secretion in healthy smokers. [Abstract 980] Scand J Gastroenterol 1982; 17: suppl 78: 247.

19 Faber RG, Hobsley M. Basal gastric secretion: reproducibility and relationship with duodenal ulceration. Gut 1977; 18: 57-63.

20 Armitage AK, Dollery CT, George CF, Houseman
TH, Lewis PJ, Turner DM. Absorption and metabolism of nicotine from cigarettes. $\mathrm{Br}$ Med J 1975; 4: 313-6.

21 Berstad A. A modified hemoglobin substrate method for the estimation of pepsin in gastric juice. Scand $J$ Gastroenterol 1970; 5: 343-8.

22 Bianchi Porro G, Parente F, Sangaletti O, Petrillo M. Relationship between serum pepsinogen I and gastric acid secretion in duodenal ulcer patients. Ital J Gastroenterol 1984; 16: 223-5.

23 Steigmann F, Dolehide RH, Kaminski L. Effects of smoking tobacco on gastric acidity and motility of hospital controls and patients with peptic ulcer. Am J Gastroenterol 1954; 22: 399-409.

24 Piper DW, Raine JM. Effect of smoking on gastric secretion. Lancet 1959; 1: 696-8.

25 Sonnenberg A, Husmert N. Effect of nicotine on gastric mucosal blood flow and acid secretion. Gut 1982; 23: 532-5.

26 Fung WP, Tye CY. Effect of smoking on gastric acid secretion. Aust N Z J Med 1973; 3: 251-4.

27 Bennett JR. Smoking and the gastrointestinal tract. Gut 1972; 13: 658-65.

28 Taylor P. Ganglionic stimulating and blocking agents. In: Goodman Gilman A, Goodman LS, Gilman A, eds. The pharmacological basis of therapeutics. New York: McMillan, 1980: 211-9.

29 Baron JH. Clinical tests of gastric secretion. History, methodology and interpretation. London and Basingstoke: Macmillan, 1978.

30 Card WI, Marks IN. The relationship between the acid output of the stomach following 'maximal' histamine stimulation and the parietal cell mass. Clin Sci 1960; 19: 147-63.

31 Waldum HL, Burhol PG, Straume BK. Serum group I pepsinogens and gastrin in relation to gastric $\mathrm{H}^{+}$and pepsin outputs before and after subcutaneous injection of pentagastrin. Scand J Gastroenterol 1978; 13: 943-6.

32 Thompson JH. Effects of nicotine and tobacco smoke on gastric secretion in rats with gastric fistulas. $A m \mathrm{~J}$ Dig Dis 1970; 15: 209-17.

33 Thompson JH, Spezia CA, Angulo M. Chronic effects of nicotine on rat gastric secretion. Experientia 1970; 26: 615-7.

34 Thompson JH, Angulo M. Chronic effects of nicotine on gastric secretion in vagotomized rats. Experientia 1971; 27: 404-5.

35 Thompson JH, George R. Chronic effects of nicotine on gastric secretion in rats with hypothalamic lesions. Am J Dig Dis 1972; 17: 313-8.

36 Ligny G, Snets P. Effect of a long term cholinergic therapy on the gastric acid secretion and on the calculated acid concentration of the parietal cell component in hypochlorhydric patients. Biomedicine 1978; 28: $35-41$.

37 Thirlby R, Feldman M. Effect of chronic, physiological vagal stimulation on maximal acid output (MAO) in dogs. Gastroenterology 1983; 84: 1334.

38 Feldman M. Gastric secretion. In: Sleisenger $\mathbf{M H}$, Fordtran JS, eds. Gastrointestinal disease. Pathophysiology, diagnosis, management. 3rd ed. Philadelphia: Saunders, 1983: 541-58. 